\title{
Confirmation of Bacteroides gingivalis as a Species Distinct from Bacteroides asaccharolyticus
}

\author{
T. J. M. VAN STEENBERGEN, C. A. VLAANDEREN, AND J. DE GRAAFF \\ Department of Oral Microbiology, Schools of Medicine and Dentistry, Free University, Amsterdam, \\ The Netherlands
}

\begin{abstract}
We divided the asaccharolytic, black-pigmented Bacteroides strains into two groups on the basis of deoxyribonucleic acid (DNA) base ratios, DNA hybridization (S1 nuclease method) results, and direct hemagglutination. One homologous group of strains, which included the type strain of Bacteroides asaccharolyticus and had guanine-plus-cytosine contents of 52 to $54 \mathrm{~mol} \%$, contained only nonoral isolates. Another DNA homology group contained all of the strains from periodontal pockets and some nonoral isolates. These strains appeared to belong to the recently described new species Bacteroides gingivalis Coykendall et al. $B$. gingivalis strains had guanine-plus-cytosine contents of 48 to $50 \mathrm{~mol} \%$, showed high DNA homology values, and shared hemagglutinating activity. No DNA homology was observed between the two groups. Using a different method of analysis for DNA homology (S1 nuclease method), we confirmed the conclusion of Coykendall et al., who separated these two groups into different species, $B$. asaccharolyticus and $B$. gingivalis. Two strains from infected root canals could not be placed in either of these two species. On the basis of the DNA homology results, all asaccharolytic strains were distinguished clearly from the saccharolytic, black-pigmented Bacteroides strains, which at present are classified in the species Bacteroides melaninogenicus.
\end{abstract}

The asaccharolytic, black-pigmented strains originally identified as members of Bacteroides melaninogenicus have been reclassified as members of Bacteroides asaccharolyticus (6). Recently, Coykendall et al. (2) proposed separating these strains into the following two different species: $B$. asaccharolyticus and a new species, Bacteroides gingivalis. $B$. asaccharolyticus strains can be isolated from many different kinds of infection (5), whereas high numbers of $B$. gingivalis are isolated from periodontal pockets $(19,22)$. The genetic heterogeneity within the group of asaccharolytic, black-pigmented Bacteroides strains is shown by the deoxyribonucleic acid (DNA) base contents of these organisms; one group has low guanine-plus-cytosine $(\mathrm{G}+\mathrm{C})$ values, and another has high $\mathrm{G}+\mathrm{C}$ values $(17,24)$. In a preliminary report $(25)$, we stated that these two groups showed no DNA-DNA hybridization. These groups were also heterogeneous with respect to polypeptide content (23), electrophoretic mobility of the enzyme malate dehydrogenase (17), fatty acid composition, and isoprenoid quinone composition (16). Differences between oral and nonoral asaccharolytic, black-pigmented Bacteroides strains were demonstrated by direct hemagglutination (20), by morphological and immunochemical methods (11), by antigenic studies $(13,15)$, and by the production of phenylacetic acid (9). In this paper we present the results of studies on DNA hybridization and $\mathrm{G}+\mathrm{C}$ contents and hemagglutination by asaccharolytic, black-pigmented $B a c$ teroides strains. Our results confirm the proposal by Coykendall et al. of a new species, $B$. gingivalis, which is different from $B$. asaccharolyticus (2).

\section{MATERIALS AND METHODS}

Bacterial strains. The strains which we studied are listed in Table 1.

Isolation of strains and maintenance of cultures. To isolate black-pigmented Bacteroides strains from periodontitis, plaque samples from deep periodontal pockets were inoculated directly onto BM blood agar plates (24), which were then incubated anaerobically at $37^{\circ} \mathrm{C}$ for at least 1 week. Black-pigmented colonies were subcultured repeatedly on the same medium until pure cultures were obtained. Strains were maintained on blood agar plates, and study cultures were grown in liquid BM medium as described previously (24).

Biochemical characteristics. Fermentation of glucose was determined by measuring the final $\mathrm{pH}$ in BM medium. Other biochemical characteristics were determined by using the API 20A system (Analytab Products, Inc.).

Hemagglutination test. Direct hemagglutination of sheep and horse erythrocytes was determined by the slide test described by Slots and Genco (21). 
TABLE 1. Strains used in this study

\begin{tabular}{|c|c|c|}
\hline Strain & Source & Site of isolation \\
\hline \multicolumn{3}{|l|}{ B. asaccharolyticus } \\
\hline ATCC 25260 (VPI 4198, B 440) & Shah $^{\alpha}$ & Empyema \\
\hline ATCC 27067 (VPI 5834) & $\mathrm{ATCC}^{b}$ & Human leg wound \\
\hline NCTC 9337 (VPI 8945) & Shah & Infected hemorrhoids \\
\hline VPI 4199 (B 477) & Shah & Human feces \\
\hline B 536 & Shah & Human feces \\
\hline \multicolumn{3}{|l|}{ B. gingivalis } \\
\hline W 83 & Shah & Clinical specimen \\
\hline 2848 & Shah & Perforated appendix \\
\hline W 50 & Shah & Clinical specimen \\
\hline 381 & Socransky $^{c}$ & Periodontitis \\
\hline 376 & Socransky & Periodontitis \\
\hline 382 & Socransky & Periodontitis \\
\hline H 184 & This laboratory & Periodontitis \\
\hline H 185 & This laboratory & Periodontitis \\
\hline H 186 & This laboratory & Periodontitis \\
\hline \multicolumn{3}{|c|}{ Asaccharolytic, black-pigmented Bacteroides strains } \\
\hline H 11 a-e & Sundqvist $^{d}$ & Infected root canal \\
\hline BN 11 a-f & Sundqvist & Infected root canal \\
\hline \multicolumn{3}{|c|}{ B. melaninogenicus subsp. melaninogenicus } \\
\hline ATCC 25845 (VPI 4196, B 282) & Shah & Sputum \\
\hline WAL 2728 & Shah & Fecal fluid \\
\hline \multicolumn{3}{|c|}{ B. melaninogenicus subsp. intermedius } \\
\hline ATCC 25611 (VPI 4197, B 422) & ATCC & Empyema \\
\hline LH 100 & Shah & Dental plaque \\
\hline \multicolumn{3}{|l|}{ "B. melaninogenicus subsp. levii" } \\
\hline Lev & Shah & Bovine rumen \\
\hline JP 2 & Shah & Unknown \\
\hline
\end{tabular}

${ }^{a}$ H. N. Shah, London Hospital Medical College, London, England.

${ }^{b}$ ATCC, American Type Culture Collection, Rockville, Md.

' S. S. Socransky, Forsyth Dental Center, Boston, Mass.

${ }^{d}$ G. Sundqvist, University of Umeå, Umeå, Sweden.

Isolation of unlabeled DNA. Unlabeled DNA was isolated from sodium dodecyl sulfate-lysed cells as described previously (24) or from cells lysed mechanically with a Vibrogen cell mill (Bühler, Tübingen, Germany) by the method of Meyer and Schleifer (12).

Isolation of ${ }^{3} \mathbf{H}$-labeled DNA. Strains were grown anaerobically at $37^{\circ} \mathrm{C}$ for $24 \mathrm{~h}$ in BM medium (17). Then the bacteria were diluted 1:100 in $10 \mathrm{ml}$ of BM medium containing $10 \mu \mathrm{Ci}$ of $\left[{ }^{3} \mathrm{H}\right]$ thymidine per $\mathrm{ml}$ or $10 \mu \mathrm{Ci}$ of $\left[{ }^{3} \mathrm{H}\right]$ deoxyadenosine (Radiochemical Centre, Amersham, England) per ml. After each culture was grown for an additional $24 \mathrm{~h}$, its purity was checked by aerobic and anaerobic incubations on blood agar plates. The cells were harvested by centrifugation, washed in $50 \mathrm{mM}$ tris(hydroxymethyl)aminomethane$5 \mathrm{mM}$ ethylenediaminetetraacetate $-50 \mathrm{mM} \mathrm{CaCl}(\mathrm{pH}$ 8.0) buffer (TES buffer), and resuspended in $3 \mathrm{ml}$ of TES buffer. The cells were lysed by adding $10 \mathrm{mg}$ of Sarkosyl (Ciba/Geigy) per $\mathrm{ml}$ and $50 \mu \mathrm{g}$ of proteinase $\mathrm{K}$ (Merck) per $\mathrm{ml}$, and the mixture was incubated for $1 \mathrm{~h}$ at $37^{\circ} \mathrm{C}$. To the lysate, we added $6 \mathrm{~g}$ of $\mathrm{CsCl}, 2.8$ $\mathrm{ml}$ of TES buffer, and $0.2 \mathrm{ml}$ of an ethidium bromide solution $(10 \mathrm{mg} / \mathrm{ml}$ in TES buffer). Density gradient centrifugation was performed with an International Equipment Co. model B 60 ultracentrifuge and a 20 $\times 14$ rotor for $48 \mathrm{~h}$ at $36,000 \mathrm{rpm}$ and $15^{\circ} \mathrm{C}$. Fractions were collected with a tube piercer (Hoefer Scientific Instruments, San Francisco, Calif.); after trichloro- acetic acid precipitation $10-\mu \mathrm{l}$ samples were counted with a Berthold liquid scintillation counter. The fractions containing the ${ }^{3} \mathrm{H}$-labeled DNA were pooled, extracted with $\mathrm{CsCl}$-saturated isopropanol to remove the ethidium bromide, and treated ultrasonically for 5 $\mathrm{s}$ with an ultrasonic disintegrator (Measuring \& Scientific Equipment, Ltd.) to shear the DNA into fragments of about 7S, as determined by sucrose gradient centrifugation. The DNA was dialyzed against $0.42 \mathrm{M}$ $\mathrm{NaCl}$. The concentration of the DNA was measured, and the purity was checked with a Gilford spectrophotometer.

DNA-DNA hybridization. A $0.013-\mu \mathrm{g}$ amount of $\left[{ }^{3} \mathrm{H}\right]$ thymidine-labeled DNA and $20 \mu \mathrm{g}$ of unlabeled DNA were mixed in $200 \mu \mathrm{l}$ of a $0.42 \mathrm{M} \mathrm{NaCl}$ solution, denatured for $10 \mathrm{~min}$ at $100^{\circ} \mathrm{C}$, and renaturated for $90 \mathrm{~h}$ at $60^{\circ} \mathrm{C}$ to obtain a $\mathrm{C}_{0} \mathrm{t}$ of $100 \mathrm{~mol} \cdot \mathrm{s} /$ liter (1). The amount of reassociation was determined by the $S 1$ nuclease method described by Crosa et al. (3), using $100 \mathrm{U}$ of $\mathrm{S} 1$ nuclease (Boehringer Mannheim Corp.) per $\mathrm{ml}$ in a $30 \mathrm{mM}$ sodium-acetate buffer ( $\mathrm{pH} 4.5)$ containing $0.1 \mathrm{mM} \mathrm{ZnSO}, 0.15 \mathrm{M} \mathrm{NaCl}$, and $20 \mu \mathrm{g}$ of sheared denaturated calf thymus DNA (type V; Sigma Chemical Co.) per $\mathrm{ml}$. The mixture was incubated for $20 \mathrm{~min}$ at $50^{\circ} \mathrm{C}$, precipitated in $5 \%$ trichloroacetic acid, and filtered on membrane filters (type HA; Millipore Corp.). The DNA was counted in a PPO (2,5-diphenyloxazole)-POPOP [1,4-bis-(5-phenyloxazolyl)ben- 
zene]-toluene scintillation mixture. Hybridization was determined as a percentage of the homologous reaction. Values were corrected for self-reassociation of the tritiated DNA; calf thymus DNA was used as a control.

Determination of DNA base composition. DNA base composition was determined both by the buoyant density method and by the thermal denaturation method. The buoyant density was determined from a $\mathrm{CsCl}$ density gradient obtained in an analytical ultracentrifuge by a previously described method (24). The midpoint of thermal denaturation was determined in a $0.15 \mathrm{M}$ sodium chloride- $0.015 \mathrm{M}$ sodium citrate buffer by the method of Mandel and Marmur (10). The temperature absorbance profile was measured with a Gilford model 250 spectrophotometer equipped with a Gilford thermoprogrammer. The $\mathrm{G}+\mathrm{C}$ contents of the DNA samples were calculated by using the formula of De Ley (4).

\section{RESULTS}

To isolate asaccharolytic, black-pigmented Bacteroides strains, plaque samples were obtained from deep periodontal pockets in 16 adult patients undergoing periodontal therapy. From these samples, we isolated 15 black-pigmented strains, 3 of which did not ferment glucose or other sugars.

Some properties of these asaccharolytic isolates and of other black-pigmented Bacteroides strains (obtained from different laboratories) are listed in Table 2 . With the asaccharolytic strains, the final $\mathrm{pH}$ in $\mathrm{BM}$ medium ranged from 6.7 to 7.3 , whereas the cultures of the saccharolytic strains of the different subspecies of $B$. melaninogenicus had terminal $\mathrm{pH}$ values of 5.0 to 5.4. All of the asaccharolytic strains from periodontal pockets agglutinated both sheep and horse erythrocytes. The three nonoral asaccharolytic isolates (isolates W 83, 2848, and W 50) were also hemagglutination positive. The other nonoral asaccharolytic strains, the two asaccharolytic strains from infected root canals (strains $\mathrm{H}$ 11 a-e and BN 11 a-f), and all of the B. melaninogenicus strains tested showed no hemagglutination. All strains were catalase negative. The $\mathrm{G}+\mathrm{C}$ contents of the DNAs of the oral and nonoral, hemagglutination-positive strains varied between 48 and $50 \mathrm{~mol} \%$. These strains were

TABLE 2. Properties of the black-pigmented Bacteroides strains studied

\begin{tabular}{|c|c|c|c|c|c|}
\hline & \multirow[b]{2}{*}{ Strain } & \multirow{2}{*}{$\begin{array}{l}\text { Final } \mathrm{pH} \\
\text { (glucose } \\
\text { medium) }\end{array}$} & \multirow{2}{*}{$\begin{array}{l}\text { Hemaggluti- } \\
\text { nation }\end{array}$} & \multicolumn{2}{|c|}{$\begin{array}{l}\mathrm{G}+\mathrm{C} \text { content (mol\%) of } \\
\text { DNA }\end{array}$} \\
\hline & & & & $\begin{array}{l}\text { Buoyant } \\
\text { density } \\
\text { method }\end{array}$ & $\begin{array}{c}\text { Melting } \\
\text { point } \\
\text { method }\end{array}$ \\
\hline \multicolumn{6}{|c|}{ B. asaccharolyticus } \\
\hline ATCC 25260 & & 6.7 & - & 53.0 & 53.8 \\
\hline ATCC 27067 & & 6.5 & - & 54.1 & 52.2 \\
\hline NCTC 9337 & & 6.6 & - & 53.0 & 52.3 \\
\hline VPI 4199 & & 7.0 & - & 54.1 & 53.7 \\
\hline В 536 & & 7.1 & - & 54.2 & $\mathrm{ND}^{a}$ \\
\hline \multicolumn{6}{|l|}{ B. gingivalis } \\
\hline W 83 & & 7.1 & + & 48.2 & 50.2 \\
\hline 2848 & & 6.5 & + & 48.0 & 49.0 \\
\hline W 50 & & 6.9 & + & 48.6 & 48.8 \\
\hline 381 & & 6.7 & + & 47.8 & 49.5 \\
\hline 376 & & 6.5 & + & 48.7 & 47.3 \\
\hline 382 & & 7.0 & + & 49.8 & ND \\
\hline H 184 & & 6.8 & + & 49.7 & ND \\
\hline H 185 & & 7.0 & + & 50.1 & ND \\
\hline H 186 & & 6.9 & + & 49.9 & ND \\
\hline \multicolumn{6}{|c|}{$\begin{array}{l}\text { Asaccharolytic, black-pigmented Bacteroides } \\
\text { strains }\end{array}$} \\
\hline H 11 a-e & & 6.9 & - & 50.6 & ND \\
\hline BN 11 a-f & & 7.0 & - & 51.1 & ND \\
\hline \multicolumn{6}{|c|}{ B. melaninogenicus subsp. melaninogenicus } \\
\hline ATCC 25845 & & 5.0 & - & 41.9 & 43.3 \\
\hline WAL 2728 & & 5.3 & - & 41.9 & 41.8 \\
\hline \multicolumn{6}{|c|}{ B. melaninogenicus subsp. intermedius } \\
\hline ATCC 25611 & & 5.3 & - & 44.6 & 42.9 \\
\hline LH 100 & & 5.2 & - & 41.6 & 42.9 \\
\hline \multicolumn{6}{|c|}{ "B. melaninogenicus subsp. levii" } \\
\hline Lev & & 5.3 & ND & 46.6 & 46.0 \\
\hline JP 2 & & 5.4 & ND & 45.0 & 46.2 \\
\hline
\end{tabular}

${ }^{a}$ ND, Not determined. 
identified as members of $B$. gingivalis (2). The asaccharolytic strains $\mathrm{H} 11$ a-e and BN 11 a-f had $\mathrm{G}+\mathrm{C}$ contents of about $51 \mathrm{~mol} \%$, whereas the asaccharolytic, hemagglutination-negative strains had G+C contents of 53 to $54 \mathrm{~mol} \%$. The latter group could be identified as strains of $B$. asaccharolyticus. The $\mathrm{G}+\mathrm{C}$ contents of the DNAs of the saccharolytic strains of the different subspecies of $B$. melaninogenicus were much lower; these values were about 42 to 44 $\mathrm{mol} \%$ for $B$. melaninogenicus subsp. melaninogenicus and $B$. melaninogenicus subsp. intermedius and about $46 \mathrm{~mol} \%$ for " $B$. melaninogenicus subsp. levii" (names in quotation marks are not on the Approved Lists of Bacterial Names [18]). There were no significant differences between the $\mathrm{G}+\mathrm{C}$ values obtained by the buoyant density and the melting point methods.

In the DNA-DNA hybridization studies, the DNAs of the two $B$. gingivalis strains (strains W 83 and 2848) were labeled with tritiated thymidine. The type strain of $B$. asaccharolyticus (strain ATCC 25260) and strain ATCC 27067 did not incorporate $\left[{ }^{3} \mathrm{H}\right]$ thymidine into their DNAs; however, the DNAs of these strains could be labeled with tritiated deoxyadenosine.

Table 3 shows the results of the hybridization experiments with these strains. The recovery of label in the homologous reaction was between 70 and $95 \%$ for strains W 83 and 2848 , and this value was between 40 and $60 \%$ for strains ATCC 25260 and ATCC 27067. These results demonstrated the existence of two main groups of asaccharolytic, black-pigmented Bacteroides strains. The five nonoral strains, including ATCC 25260, form a rather homogeneous group, which has DNA homology values of 64 to $100 \%$. The DNA hybridization values with $B$. gingivalis and $B$. melaninogenicus strains were less than $20 \%$. The second homology group, corresponding to $B$. gingivalis, included the nonoral strains W 83, 2848, and W 50 and all of the asaccharolytic strains isolated from periodontal pockets; these strains showed DNA homology values of 67 to $100 \%$ with each other and of $22 \%$ or less with saccharolytic and other asaccharolytic strains. Strains H 11 a-e and BN 11 a-f could not be placed in either of these two groups.

TABLE 3. Relative hybridization of DNAs from black-pigmented Bacteroides strains with reference DNAs from four asaccharolytic strains

\begin{tabular}{|c|c|c|c|c|c|}
\hline \multirow{2}{*}{ Source of unlabeled DNA } & \multirow{2}{*}{$\begin{array}{c}\text { Mean } \\
\text { G+C con- } \\
\text { tent of } \\
\text { DNA } \\
(\mathrm{mol} \%)\end{array}$} & \multicolumn{4}{|c|}{$\begin{array}{c}\text { Relative \% hybridization to labeled reference } \\
\text { DNA from: }\end{array}$} \\
\hline & & $\begin{array}{l}\text { ATCC } \\
25260\end{array}$ & $\begin{array}{l}\text { ATCC } \\
27067 \\
\end{array}$ & W 83 & 2848 \\
\hline \multicolumn{6}{|l|}{ B. asaccharolyticus } \\
\hline ATCC 25260 & 53 & 100 & 70 & 22 & 8 \\
\hline ATCC 27067 & 53 & 72 & 100 & $\mathrm{ND}^{a}$ & 4 \\
\hline NCTC 9337 & 53 & 66 & 72 & 1 & 6 \\
\hline VPI 4199 & 54 & 72 & 64 & 1 & 20 \\
\hline B 536 & 54 & 72 & ND & 0 & 6 \\
\hline \multicolumn{6}{|l|}{ B. gingivalis } \\
\hline W 83 & 49 & 9 & 8 & 100 & 86 \\
\hline 2848 & 48 & 19 & ND & 67 & 100 \\
\hline W 50 & 49 & 17 & 6 & 98 & 100 \\
\hline 381 & 49 & 7 & 2 & 81 & 92 \\
\hline 376 & 48 & 0 & ND & 85 & 81 \\
\hline 382 & 50 & 0 & ND & 83 & 79 \\
\hline H 184 & 50 & ND & ND & 85 & 87 \\
\hline H 185 & 50 & 10 & ND & 81 & 72 \\
\hline H 186 & 50 & 20 & ND & 88 & 80 \\
\hline \multicolumn{6}{|c|}{$\begin{array}{l}\text { Asaccharolytic, black-pigmented Bacteroides } \\
\text { strains }\end{array}$} \\
\hline H 11 a-e & 51 & 6 & ND & 0 & 5 \\
\hline BN 11 a-f & 51 & 20 & ND & 0 & $\cdot 15$ \\
\hline \multicolumn{6}{|c|}{ B. melaninogenicus subsp. melaninogenicus } \\
\hline ATCC 25845 & 43 & 2 & 0 & 0 & ND \\
\hline WAL 2728 & 42 & ND & ND & 0 & 20 \\
\hline \multicolumn{6}{|l|}{ B. melaninogenicus subsp. intermedius } \\
\hline ATCC 25611 & 44 & 0 & ND & 1 & ND \\
\hline LH 100 & 42 & 0 & 18 & 1 & ND \\
\hline \multicolumn{6}{|l|}{ "B. melaninogenicus subsp. levii" } \\
\hline Lev & 46 & 10 & 3 & 3 & ND \\
\hline JP 2 & 46 & ND & ND & ND & 1 \\
\hline
\end{tabular}

${ }^{a} \mathrm{ND}$, Not determined. 


\section{DISCUSSION}

There has been considerable confusion concerning the taxonomy of black-pigmented $\mathrm{Bac}$ teroides strains. In Bergey's Manual of Determinative Bacteriology, 8th ed., the following three different subspecies of $B$. melaninogenicus were described (8): $B$. melaninogenicus subsp. melaninogenicus, $B$. melaninogenicus subsp. intermedius, and "B. melaninogenicus subsp. asaccharolyticus." Subsequently, two other subspecies were added, " $B$. melaninogenicus subsp. levii" and $B$. melaninogenicus subsp. macacae $(7,21)$. The asaccharolytic strains have been reclassified as a separate species, $B$. asaccharolyticus (Holdeman and Moore) Finegold and Barnes (6). Recently, Coykendall et al. (2) proposed separating these asaccharolytic strains into the following two species on the basis of DNA homology relationships: $B$. asaccharolyticus, containing the nonoral strains, and $B$. gingivalis, containing the oral strains, mostly from periodontal pockets. In the study reported here, we confirmed the existence of these two groups of strains on the basis of DNA-DNA hybridization, DNA base contents, and hemagglutination activity.

Hemagglutination by 29 of 59 black-pigmented Bacteroides strains was reported by Okuda and Takazoe (14); however, these authors did not identify these strains at the subspecies level. Slots and Genco (20) reported that oral asaccharolytic strains agglutinate sheep erythrocytes, whereas nonoral strains do not. Our results generally agree with this observation; i.e., all of the strains from periodontal pockets which we studied were hemagglutination positive. However, we also found three nonoral strains that agglutinated erythrocytes. Therefore, we conclude that hemagglutination is a property of $B$. gingivalis that can be used as an easy and valuable differential character for this species. If one assumes that dental plaque is the ecological niche for $B$. gingivalis, this could mean that the nonoral hemagglutinating strains of $B$. gingivalis originate from the oral cavity. Strains $H$ 11 a-e and BN 11 a-f, which were isolated from infected root canals, were hemagglutination negative and did not belong to either $B$. gingivalis or B. asaccharolyticus. From these observations, we conclude that in order to identify an isolate, a worker should not rely merely on the site of isolation (either oral or nonoral), for obviously there are different ecological niches within the oral cavity which harbor different organisms; besides, it is possible that strains migrate to different parts of the body.

In general, the $\mathrm{G}+\mathrm{C}$ contents which we found confirm previous observations $(2,6,17,24)$. Con- trary to the results of Coykendall et al. (2), we did not find a low (with respect to other $B$. asaccharolyticus strains) $\mathrm{G}+\mathrm{C}$ content in the DNA of strain B536. Because of differences between laboratories, it is difficult to compare the $\mathrm{G}+\mathrm{C}$ values obtained by different workers for the same strains. In this study, both the melting point method and the buoyant density method were used to determine the $\mathrm{G}+\mathrm{C}$ contents of the DNAs; however, we consider the values obtained by the buoyant density method more reliable because this method is less sensitive to impurities in DNA preparations (24).

We have described previously the existence of two DNA homology groups of asaccharolytic strains (25). Johnson and Moore reported the existence of the same two main DNA homology groups of asaccharolytic, black-pigmented $\mathrm{Bac}$ teroides strains (J. L. Johnson and W. E. C. Moore, J. Dent. Res. 59A:511, 1980).

Recently, Coykendall et al. (2) proposed the species $B$. gingivalis as a species distinct from $B$. asaccharolyticus. Our results, which were obtained by using a different method to detect DNA-DNA homology, essentially confirm this proposal. Furthermore, our DNA hybridization studies strengthen the conclusion that all asaccharolytic strains should be separated from strains of $B$. melaninogenicus.

In this work, only a limited number of strains were studied. We expect that additional studies of more asaccharolytic, black-pigmented Bacteroides strains will reveal additional groups. The strains which were isolated from infected root canals and which we were unable to identify as either B. asaccharolyticus or B. gingivalis probably represent such a new group of strains, and very likely they will have to be placed into a new species.

\section{ACKNOWLEDGMENTS}

We thank H. N. Shah, G. Sundqvist, and S. S. Socransky for providing strains. We acknowledge the department of periodontology for plaque samples. We also thank J. J. de Soet for his valuable technical assistance.

\section{REPRINT REQUESTS}

Address reprint requests to: T. J. M. van Steenbergen, Department of Oral Microbiology, Free University, v.d.Boechorststraat 7, 1081 BT Amsterdam, The Netherlands.

\section{LTTERATURE CITED}

1. Britten, R. J., and D. E. Kohne. 1967. Nucleotide sequence repetition in DNA. Carnegie Inst. Washington Yearb. 65: 78-105.

2. Coykendall, A. L., F. S. Kaczmarek, and J. Slots. 1980. Genetic heterogeneity in Bacteroides asaccharolyticus (Holdeman and Moore 1970) Finegold and Barnes 1977 (Approved Lists, 1980) and proposal of Bacteroides gingivalis sp. nov. and Bacteroides macacae (Slots and Genco) comb. nov. Int. J. Syst. Bac- 
teriol. 30:559-564.

3. Crosa, J. H., D. J. Brenner, and S. Falkow. 1973. Use of a single-strand-specific nuclease for analysis of bacterial and plasmid deoxyribonucleic acid homo- and heteroduplexes. J. Bacteriol. 115:904-911.

4. De Ley, J. 1970. Reexamination of the association between melting point, buoyant density and chemical base composition of deoxyribonucleic acid. J. Bacteriol. 101: 738-754.

5. Finegold, S. M. 1977. Anaerobic bacteria in human disease. Academic Press, Inc., New York.

6. Finegold, S. M., and E. M. Barnes. 1977. Report of the ICSB Taxonomic Subcommittee on Gram-Negative Anaerobic Rods. Proposal that the saccharolytic and asaccharolytic strains at present classified in the species Bacteroides melaninogenicus (Oliver and Wherry) be reclassified into two species as Bacteroides melaninogenicus and Bacteroides asaccharolyticus. Int. J. Syst. Bacteriol. 27:388-391.

7. Holdeman, L. V., E. P. Cato, and W. E. C. Moore. 1977. Anaerobe laboratory manual, 4 th ed. Virginia Polytechnic Institute and State University, Blacksburg.

8. Holdeman, L. V., and W. E. C. Moore. 1974. Genus I, Bacteroides Castellani and Chalmers 1919, 959, p. 385404. In R. E. Buchanan and N. E. Gibbons (ed.), Bergey's manual of determinative bacteriology, 8 th ed. The Williams \& Wilkins Co., Baltimore.

9. Kaszmarek, F. S., and A. L. Coykendall. 1980. Production of phenylacetic acid by strains of Bacteroides asaccharolyticus and Bacteroides gingivalis (sp. nov.). J. Clin. Microbiol. 12:288-290.

10. Mandel, M., and J. Marmur. 1968. Use of ultraviolet absorbance-temperature profile for determining the guanine plus cytosine content of DNA. Methods Enzymol. 12B:195-206.

11. Mansheim, B. J., and S. E. Coleman. 1980. Immunochemical differences between oral and nonoral strains of Bacteroides asaccharolyticus. Infect. Immun. 27: 589-596.

12. Meyer, S. A., and K. H. Schleifer. 1975. Rapid procedure for the approximate determination of the deoxyribonucleic acid base composition of micrococci, staphylococci, and other bacteria. Int. J. Syst. Bacteriol. 25: 383-385.

13. Mouton, C., P. Hammond, J. Slots, and R. J. Genco. 1980. Evaluation of Fluorotec-M for detection of oral strains of Bacteroides asaccharolyticus and Bacte- roides melaninogenicus. J. Clin. Microbiol. 11:682-688.

14. Okuda, K., and I. Takazoe. 1974. Haemagglutinating activity of Bacteroides melaninogenicus. Arch. Oral Biol. 19:415-416.

15. Reed, M. J., J. Slots, C. Mouton, and R. J. Genco. 1980. Antigenic studies of oral and nonoral black-pigmented Bacteroides strains. Infect. Immun. 29:564574.

16. Shah, H. N., and M. D. Collins. 1980. Fatty acid and isoprenoid quinone composition in the classification of Bacteroides melaninogenicus and related taxa. J. Appl. Bacteriol. 48: 75-87.

17. Shah, H. N., R. A. D. Williams, G. H. Bowden, and J. M. Hardie. 1976. Comparison of the biochemical properties of Bacteroides melaninogenicus from human dental plaque and other sites. J. Appl. Bacteriol. 41: 473-492.

18. Skerman, V. B. D., V. McGowan, and P. H. A. Sneath (ed.). 1980. Approved lists of bacterial names. Int. J. Syst. Bacteriol. 30:225-420.

19. Slots, J. 1979. Subgingival microflora and periodontal disease. J. Clin. Periodontol. 6:351-382.

20. Slots, J., and R. J. Genco. 1979. Direct hemagglutination technique for differentiating Bacteroides asaccharolyticus oral strains from nonoral strains. J. Clin. Microbiol. 10:371-373.

21. Slots, J., and R. J. Genco. 1980. Bacteroides melaninogenicus subsp. macacae, a new subspecies from monkey periodontopathic indigenous microflora. Int. $J$. Syst. Bacteriol. 30:82-85.

22. Spiegel, C. A., S. E. Hayduk, G. E. Minah, and G. N. Krywolap. 1979. Black-pigmented Bacteroides from clinically characterized periodontal sites. J. Periodontal Res. 14:376-382.

23. Swindlehurst, C. A., H. N. Shah, C. W. Parr, and R. A. D. Williams. 1977. Sodium dodecyl sulphate-polyacrylamide gel electrophoresis of polypeptides from Bacteroides melaninogenicus. J. Appl. Bacteriol. 43: 319-324.

24. van Steenbergen, T. J. M., J. J. de Soet, and J. de Graaff. 1979. DNA base composition of various strains of Bacteroides melaninogenicus. FEMS Microbiol. Lett. 5:127-130.

25. van Steenbergen, T. J. M., J. J. de Soet, and J. de Graaff. 1979. Genetic relationship between different subspecies of Bacteroides melaninogenicus. Antonje van Leeuwenhoek J. Microbiol. Serol. 45:513. 